\title{
Refik Halit Karay'ın "Yatık Emine"sine Gayri İnsanileştirme Olgusu Çerçevesinde Bir Bakış
}

\section{An Analysis of Refik Halit Karay's "Yatı Emine" within the Framework of the Dehumanization Phenomenon}

\author{
Zeynep TEK ${ }^{*}$ \\ Emine YÜCEL**
}

$\ddot{\boldsymbol{O}} \boldsymbol{z}$ Görünürdeki benzerlik ve farklılıklarımız bir yana, toplumu temsil eden pek çok farklı kesimle ortak bir özü paylaşırız; insan oluşu. Toplumu oluşturan tüm fert ve grupları ortak insanlık paydasında bir araya getirebilmek, biz ve öteki arasındaki kalın duvarları yıkma potansiyeli taşır. Ancak toplumsal yaşama baktığımızda doğal bir kategori olarak insanlığın bazı insan ya da gruplara yakıştırılmadığı ve onların kategorik açıdan insanlıktan men edilmiş olduklarını görürüz. Gayri insanileştirme adı verilen bu olgu, bunu gerçekleştiren failin hedef aldığı kişi ya da gruplara karşı sosyal mesafenin artmasına sebebiyet verir. Sonuçta kendisini daha fazla insan addeden kişi, insan addetmediği ötekine üstünlük taslar, onu yok sayar ve ona karşı her türlü insanlık dıșı muameleyi reva görmeye başlar. Refik Halit Karay'ın (18881965) "Yatık Emine" (1918) isimli hikâyesi insanlığın bir türlü kondurulamadığı bir hayat kadını özelinde gayri insanileştirme olgusuna ve bunun trajik sonuçlarına kurgusal düzeyde çarpıcı bir biçimde ışık tutar. Buradan hareketle, mevcut makalede Emine'nin hem devletin temsilcileri hem de sürgün edildiği kasabanın halkı tarafından (kadınlar ve erkekler) hangi gerekçe ve unsurlarla insan dışı görüldüğü gözler önüne serilmektedir. Ayrıca Emine'nin kişiliği, farklı durumlardaki tepkileri ya da tepkisizliği ve hayatta kalma mücadelesi ele alınarak onun kendisini bir insan olarak nerede konumlandırıldığı da sorgulanmaktadır.

Anahtar sözcükler: Refik Halit Karay, "Yatık Emine”, Gayri İnsanileştirme, Edebî Metin Analizi

Abstract: Aside from our ostensible similarities and differences, we share a common essence with all groups in society - our humanness. Uniting all the different peoples under the umbrella of our common humanity has the potential to demolish the thick walls between us and the other. However, a quick look at society, shows that humanity is not ascribed to certain people or groups, and those people are categorically omitted from humanness. This phenomenon is termed dehumanization, and it deepens the social distance between the dehumanizer and those who are dehumanized. Consequently, a person who attributes greater humanness to oneself, claims superiority over the dehumanized others, can totally ignore them, and justify all kinds of inhumane treatment against them. Revolving around the story of a prostitute, "Yatık Emine" (1918) by Refik Halit Karay (1888-1965) sheds light upon the practice of dehumanization and its tragic consequences in a fictional ground. Relatedly, the current article examines how and for what reasons Emine has been dehumanized by both governmental representatives and the villagers (women and men). Additionally, how Emine positions herself as a human being is also considered with regards to her personality, her reactions / unresponsiveness in certain situations, and her struggle for survival.

Keywords: Refik Halit Karay, "Yatık Emine”, Dehumanization, Literary Text Analysis

\footnotetext{
* Dr., Ankara Yıldırım Beyazıt Üniversitesi, İnsan ve Toplum Bilimleri Fakültesi, Türk Dili ve Edebiyatı Bölümü, Ankara. ztek@ybu.edu.tr, https://orcid.org/0000-0003-2577-6422

** Arş. Gör., Selçuk Üniversitesi, Edebiyat Fakültesi, Psikoloji Bölümü, Konya. ey.emineyucel@gmail.com, https://orcid.org/0000-0003-3663-6003
} 


\section{Giriş}

Popüler kültür ve yazında ırk, millet ya da etnik köken açısından ötekini temsil eden kişilerin kültür ve medeniyetten yoksun; ahlaki değerlerden uzak; bilişsel açidan yeterince gelişmemiş;; saldırganlık, cinsellik vb. dürtülerini kontrol edemeyen ve suç işlemeye meyyal kişiler olarak sunulmalarına sıklıkla tanık oluruz (Haslam 2006, 252). Ötekine ilişkin farklı temsillerdeki ortak yön, bu kategoriye girenlerin açık ya da örtük bir biçimde hayvanlarla eş tutulmaları, diğer bir ifade ile onların insan dışı varlıklar olarak konumlandırılmalarıdır. Hedefteki kişi ya da grupların tam anlamıyla insan olmadığı, insan türünü temsil etme kabiliyetinden yoksun olduğu hatta insandan daha aşağı görülen insan dışı ya da insanüstü varlıklarla ilişkilendirildiği bu algı, gayri insanileştirme (dehumanization) olarak tanımlanır (Haslam 2006, 252; Haslam \& Loughnan 2014, 402). Ötekinin insan oluşunu yadsıyan bu inanç olumsuz çağrışımlara sahiptir. Çünkü insan dışı addedilen varlık çoğu zaman korku ve tiksinti uyandırır. Gayri insanileştirmeyi uygulayan taraf, karşısındaki varlığ 258). Bu şekilde hedefteki kişiye ya da gruba yönelik saldırganlık, aşağılama, yok sayma ve ayrımcılık gibi her türlü olumsuz uygulamayı meşrulaştırıp önemsizleştirir hatta inkâr etmeye kadar gidebilir (Bandura 1990, 200). Beyaz adamın vahşi, geri kalmış ve cinlenmiş addettiği yerlileri medenileştirmeyi kendine bir görev olarak benimsemesi ya da sosyal düzeni bozdukları gerekçesiyle parazit ya da keneler olarak yaftalanan Yahudiler, Çingeneler ve Polonyalıların Nazi zulmüne reva görülmesi bu alg1 çerçevesinde değerlendirilebilir (Haslam 2006, 252). Göçmen krizinin yaşandığ 1 günümüz dünyasında ise sığınmacılar çoğunlukla gayri insani bir temsil üzerinden algılanmakta ve sığınma talebiyle sınırlarına dayandıkları ülkelerden içeri alınmama ya da her an kapı dışarı edilme tehdidi ile günlük hayatlarını sürdürmektedirler (Esses et al. 2013, 518).

Gayri insanileştirme sadece gruplar arası ilişkiler bağlamında değil toplumsal cinsiyet söz konusu olduğunda da sıklıkla gözlemlenen bir olgudur. Örneğin, kadınlar hem cinselliğe hem de fiziksel çekiciliğe yapılan açıktan vurgu ile çoğu zaman nesneleştirilir (Morris et al. 2018, 1302). Bir nesne olarak görülen kadın da aslında insan oluşundan soyutlanmakta, onun insani özellikleri yok sayılmaktadır. Ayrıca gayri insanileştirme taciz, tecavüz gibi kadını kurban konumuna düşüren olumsuz eylemlere meşrulaştırıcı bir zemin hazırlarken kadını hedef alan bu tür ahlak dış1 uygulamalara karşı sergilenen toplumsal bir kayıtsızlığ da beraberinde getirir (Morris et al. 2018, 1302). Refik Halit Karay'nn (1888-1965) bir hayat kadınının Anadolu'da geçen sürgün günlerini kaleme aldığı "Yatık Emine" (1918) hikâyesinde görüldüğü gibi bu durumun telafisi olmayan trajik sonuçları da olabilmektedir. Bu çerçevede "Yatık Emine", gayri insanileştirme olgusunu hem bunu gerçekleştiren faillerin motivasyonlarını hem de mağdur edilenin hayatta kalma mücadelesini gözler önüne sermesi bakımından oldukça çarpıcı bir metindir. Ahlaki değerlerden uzak (biri) olarak görülmesi sonucunda cezasını çekmek üzere gönderildiği kasabada, Emine'nin kendi hayatı üzerinde söz sahibi olması hiçbir şekilde mümkün olmaz ve onun beslenme, barınma ve güvenlik gibi en temel insani ihtiyaçlarının karşılanması dahi kasaba halkının insafına bırakılır. İnsanlık onuru her defasında hiçe sayılan ve peyderpey ölüme terk edilen Emine'nin içinde bulunduğu zor durum, kasaba halkına göre Emine'nin hak ettiği bir sonuçtur. Bu noktada gayri insanileştirmeyi uygulayan tarafin başka bir insanın acısı karşısında herhangi bir ahlaki sorumluluk hissetmediği ve öteki ile empati kurma becerisini kaybettiği ileri sürülebilir. Bu soğukluk, hissizlik ve kayıtsızlığg ustalıkla kurgusal bir düzleme taşıyan Karay'ın "Yatık Emine" isimli hikâyesi, bu çalışma kapsamında gayri insanileştirme yaklaşımı çerçevesinde derinlemesine bir analize tabi tutulacaktır. Bu çerçevede makalenin akışı içerisinde öncelikle gayri insanileştirme olgusuna kuramsal bir giriş yapılacaktır. Ardından hayat kadınlarının modern Türk edebiyatının ilk dönem anlatılarındaki temsili ile karşılaştırılmalı bir biçimde "Yatık Emine" hikâyesinin hayat kadının çoğunlukla görmezlikten gelinen ancak çok gerçek olan insan oluşuna yaptığı vurgu ele alınacaktır. Sonrasında ise 
anlatıda hem devletin temsilcileri hem de kasaba halkının Emine'nin insan oluşunu yadsıma biçimleri gözden geçirilecektir.

\section{Gayri İnsanileștirme ve Hedef Alınan Olarak Kadın}

Gayri insanileştirme, belirli bir kişi ya da toplumsal grubun insanı insan yapan niteliklerden yoksun olduğunu ya da onların bu tür bir insani öze sahip olmadıklarını ileri sürmektir. İnsanoğlunun sahip olduğu bazı özelliklerin insanı insan yaptığı ya da insan olmayı belirlemede kilit bir noktada durduğu düşünülür. Gayri insanileştirme yaklaşımına göre bu insani nitelikleri iki boyut üzerinden anlamlandırmak mümkündür (Haslam 2006, 252; Haslam \& Loughnan 2014, 399). Bu boyutlardan ilki insanı hayvandan ayıran ak1, ahlak, medeniyet, nezaket ve temizlik gibi insana özgü vasıflara karşılık gelir. İkinci boyut ise insanı robotlar ya da diğer cansız varlıklardan ayıran duygulanma, samimiyet, esneklik, derinlik ve özgür irade gibi insan doğasına has niteliklere karşılık gelir. Insana özgü vasıfların ne olduğu kültürden kültüre değişir ve bireyin sosyalizasyon sürecinde bu nitelikleri gelişimsel bir başarı olarak kazanması beklenir. Hedefteki kişinin insana özgü vasıfları reddedildiğinde bu kişi belli bir görgü ve kültüre sahip olamayan, geri kalmış, çocuksu, irrasyonel, kendi kendini kontrol edemeyen, ahlaki açıdan yozlaşmış bir varlık olarak algılanır ve dolayısıyla bu kişi hayvana benzetilmek suretiyle gayri insanileştirilir (hayvani gayri insanileştirme). Insan doğasına has nitelikler ise biyolojik bir miras olarak doğuştan getirilir, şu hâlde kültürden kültüre değişmez ve evrenseldir. Hedefteki kişinin insan doğasına has nitelikleri reddedildiğinde bu kişi soğuk, katı, eylemsiz ve derinlikten yoksun olarak algılanır ve dolayısıyla bu kişinin cansız bir nesne, makine ya da robota benzetilmek suretiyle gayri insanileştirildiği ileri sürülebilir (mekanik gayri insanileştirme). Hayvani ve mekanik formlarına ek olarak ötekinin tabiatüstü güçlere sahip şeytan, cadı ya da cin gibi varlıklarla eş tutularak da gayri insanileştirilmesi mümkün olabilir (Bar-Tal 1989, 172).

Özellikle soykırım, etnik çatışmalar ve göç gibi olgularda hayvani gayri insanileştirmenin etkilerini görebilmek mümkündür. Hayvanla eş tutulan, çoğunlukla hakir görülen ve geri kalmışlıkları sebebiyle ahlaki bir tiksinti uyandıran kişi ya da grupların kendi varlıklarından utanç duyması beklenir (Haslam 2006, 258). Onların toplumsal yaşama aktif katılımları sürekli bir şekilde engellenerek cesaretleri ve kendilerine olan güvenleri kırılmaya çalışılır (ÇevikErsaydı 2011, 105). Mekanik açıdan gayri insanileştirilen kişi ya da gruplar ise tiksinti kadar güçlü bir duygu uyandırmazlar. Aksine soğuk, robotik ve duygulanma kapasitesinden yoksun addedilen bu kimselere karşı olumlu ya da olumsuz bir şeyler hissetmek zorlaşır. Şu hâlde mekanik gayri insanileştirmenin hissizleşmeyi beraberinde getirdiği söylenebilir (Haslam 2006, 258). Örneğin, çok sık ölüm vakaları ile karşılaşan doktorların ölüm olgusunu dehşet ve üzüntü yerine soğukkanlılıkla karşılamaları onların hastaları mekanik açıdan gayri insanileştirmeleri ile ilişkilidir. Ancak hayvani gayri insanileştirme durumunda, failler gayri insanileştirdikleri kişi ya da grupların ayrımcılık, dışlanma, yok sayılma ya da şiddet karşısında acı duyabildiklerinin oldukça farkındadır; fakat onlara karşı herhangi bir şefkat ve empati hissetmezler (Cehajic et al. 2009, 715). Tam bu sebeple açık ya da örtük bir biçimde özellikle hayvanlarla eş tutulan insanları hedef alan ahlak dışı pek çok uygulamanın onların canını bile isteye yakmayı hedeflediği söylenebilir. Üstelik failler insanlık dışı eylemlerinden ötürü herhangi bir ahlaki sorumluluk da hissetmedikleri için başkalarının hayatlarında bıraktıkları tahribatı önemsizleştirirler. Bu kayıtsızlığı ahlaki uzaklaşma olarak adlandıran Bandura'ya $(1999,200)$ göre kişiler gayri insanileştirme vasıtası ile belli gruplara karşı sergiledikleri ahlaki ihlallerini meşru bir zemine taşımış olurlar.

Kadınlar da kimi zaman cinsellikleri kimi zaman da bedensel özellikleri ekseninde gayri insani bir temsil üzerinden algılanır. Cinsellikleri vurgulanan kadınların kültür, akıl ve yetkinlik gibi insana özgü vasıflarının azımsandığı (dolayısıyla hayvanlara benzetildiği), bedensel 
güzellikleri vurgulanan kadınların ise psikolojik sıcaklık ve sevecenlik gibi insan doğasına has niteliklerinin yadsındığ 1 (dolayısıyla makine ya da robotlara benzetildiği) görülür (Morris et al. 2018, 1302). Bu bulgu 1şı̆̆ında kadınların hem mekanik hem de hayvani açıdan gayri insanileştirilmeye maruz kalabildiğini öne sürmek mümkündür. Ayrıca pek çok kültürde hayvani, çocuksu ve ilkel olanla eş tutulan kadınlar erkeklere göre daha az insanmış gibi algılanabilmekte; bunun da temelinde kadınların doğayı aşabilme konusunda erkeklerden geride kaldığ 1 ve yeterince medenileşemediğine dair bir inanış etkili olabilmektedir (Haslam 2006, 253). Hem Amerika'da (Heflick \& Goldenberg 2009, 598) hem de İtalya'da (Vaes et al. 2011, 774) yürütülen iki ayrı çalışmada, gayri insani bir temsil üzerinden algılanan kadınlara yetkinlik, kültür ve değerler gibi insana özgü vasıflar ile merak ve yardımseverlik gibi insan doğasına has vasıfların daha az atfedildiği görülür. Üstelik sadece erkekler değil kadınlar da cinsel özellikleri ile ön plana çıkan kadınlara, insanı hayvandan ayıran vasıfları daha az atfedebilmektedirler (Vaes et al. 2011, 774).

\section{Türk Edebiyatında Hayat Kadınının Temsili: "Yatık Emine"}

"Yatık Emine", bir hayat kadınına kondurulamayan insanlığın nasıl ölebildiğini gözler önüne sermesi bakımından oldukça çarpıcı bir metin olarak karşımıza çıkar. Refik Halit Karay'ın (1888-1965) bu metni ve Anadolu'yu konu alan diğer hikâyelerinin de yer aldığı Memleket Hikâyeleri 1919'da yayımlanmıştır. Ancak "Yatık Emine" hikâye kitabına girmeden önce, 1918 yılının Ağustos ayında Yeni Мecmua'nın 56-58. sayılarında üç parça olarak neşredilmiştir. "Kirpi" mahlasıyla kaleme aldığg mizahi, hiciv yüklü yazıları ile tanınan Refik Halit, İttihat ve Terakki Partisi yönetimi aleyhine yazılar kaleme almasından dolayı uzun yıllar Sinop, Çorum, Ankara, Bilecik gibi şehirlerde sürgün olarak yaşamak zorunda bırakılmıştır. Yazarın "Yatık Emine" ve Memleket Hikâyeleri'ndeki diğer hikâyeleri, bu sürgün yıllarının izlenimlerinden esinlenilerek oluşturulan metinler olarak edebiyat tarihinde yer bulur.

"Yatık Emine", Birinci Dünya Savaşı'nın sonlarına doğru Ankara'dan ücra bir kasabaya sürgün edilen Emine adlı bir hayat kadınının ölümle sonlanan trajik öyküsünü konu alır. Cinselliği ile öne çıkan hayat kadını, Güncel Türkçe Sözlük'te para karşılığında erkeklerin cinsel zevklerine hizmet eden ve bu işi meslek edinen kadın olarak tanımlanır (TDK n.d.). İlk dönem Türk romanında da hayat kadınının genellikle maddi ihtiyaçlarını önceleyen bu yönüne odaklanıldığ 1 hatta söz konusu menfaatlerin onu çıkar odaklı ve yoldan çıkaran bir kişi hâline getirdiği üzerinde durulur. Örneğin, ilk edebî roman olarak kabul edilen Namık Kemal'in (18401888) İtibah romanında Mehpeyker, insanları kullanan ve hırsları uğruna kötülükler yapan acımasız bir tip olarak yansitılır. Nabizade Nazım'ın (1862-1893) Zehra romanında Ürani; romanın merkezi kişisi Zehra tarafından öç amaçlı parayla tutulan ve birçok insanın hayatını karartan olumsuz bir figür olarak dikkat çeker. Hüseyin Rahmi Gürpınar'ın (1864-1944) Mürebbiye romanında Angel isimli Fransız bir hayat kadınının mürebbiye olarak çalıştığ 1 konakta herkesi aldattığı işlenir. Halit Ziya Uşaklıgil'in (1865-1945) Sefile'sinde arzularının sevki ile hayat kadınlığı yaptığına tanık olunan Mihriban Hanım'ın hem kızı İkbal'in hem de evine sığınan, kimsesiz bir kız olan Mazlume'nin fuhşa sürüklenmesinde önemli amillerden biri olduğu görülür. $\mathrm{Bu}$ anlatılarda toplumsal normları çiğnemesi itibarıyla hayat kadınının genellikle karanlık ve şeytani yönleriyle öne çıkarıldığı, masum insanları özellikle de dönemin tecrübesiz gençlerini baştan çıkartan kötü bir kadın olarak kurgulandığı fark edilir. Fakat burada Ahmet Mithat Efendi’nin (1844-1912) "Mihnetkeşan" hikâyesi ile Henüz On Yedi Yaşında adlı romanında, hayat kadınının düştükleri yerden kurtarılması ve merhamet edilmesi gerekli kişiler olarak yansıtıldığı belirtilmelidir.

Oldukça insani yönleri (ihtiyaçları) ve onu değersizleştiren, yok sayan toplumun algısı ve muamelesiyle bir arada sunulan Karay'ın Yatık Emine'si, hayat kadınlarına ilişkin yukarıda bahsedilen niteliklerden farklı olarak bazı karakteristik özellikler taşır. O ne kötü bir kişi olarak 
ne de yazarın olması gerektiğini düşündüğü olumlu davranış biçimlerinin uygulandığı bir timsal olarak sunulur. Onun kimseye zarar vermek istemeyen tutumu, kendi hâlinde bir kadın oluşu, tabii istek ve hâlleri onu alışkın olunan kötü hayat kadını tipinden farklı bir yerde tutar. Emine'nin bu kendine özgülüğü, Refik Halit'in diğer edebî anlatılarındaki yeri için de söz konusudur. Aktaş'a (2004, 80-82) göre, yazarın diğer anlatılarında hayat kadınları yalnızca fiziksel özellikleri ve görevleriyle sunulduğu hâlde; bu hikâyedeki kadın, iç dünyası ve toplumsal yaşamdaki konumu ile gözler önüne serilir. Dolayısıyla söz konusu anlatıyı, hayat kadınının çok yönlü bir biçimde kurgulandığı bir metin olarak değerlendirebilmek mümkündür.

"Yatık Emine" hikâyesinde Ankara'da birtakım "uygunsuzluklara sebebiyet ver"en, Emine'nin maceras1, "Ankara'ya iki gün öte, ana yollardan aykırı küçük bir kasaba”ya (1918a, 79) gönderilmekle başlar. Onun, sürgün edildiği kasabada başta devleti temsil eden kurum ve kişiler olmak üzere toplumun her kesimi tarafindan ötekileştirilerek açlığa ve yok oluşa mahkûm edildiği görülür. Ötekileştirmenin gayri insanileştirmeye vardığı hikâyede söz konusu durumun boyutlarını sunabilmek için gayri insanileştirmeyi gerçekleştiren tarafla buna maruz kalan tarafın motivasyonlarını ve pozisyonlarını ortaya koymak gerekir. Bu şekilde gayri insanileştirmenin tarafları arasında oluşan mesafenin kurgusal iz düşümü daha iyi bir biçimde anlaşılabilir.

\section{Gayri İnsanileştirmeyi Uygulayan Taraf: Devlet Mercileri ve Toplum}

Osmanlı Devleti'nin özellikle son dönemlerinde fuhşun arttığı ve hayat kadını sayısında ciddi bir yükselişin görüldüğü bilinmektedir. 1914-1933 y1llarında İstanbul'da fuhuş ve zührevi hastalıkların tarihçesine yer veren Toprak (2015, 117-123), Meşrutiyet'ten Cumhuriyet'e geçiş evresindeki siyasal iklime paralel bir şekilde fuhuş, içki, kokain ve kumarın Türkiye'deki toplumsal çöküşün bir delili olarak arttığını ifade eder. Türkçe roman ve hikâyelerde bu dört unsurun en etkin bir şekilde işlendiği dönem de Birinci Dünya Savaşı ve Mütareke yılları olur. Bu durum Osmanlı toplumunun Dünya Savaşı'yla birlikte değer normlarının alt üst olmasıyla yakından ilgilidir. Özellikle savaş koşullarının beraberinde getirdiği yoksulluk, ahlaki çöküntünün temel sebebi olarak ortaya çıkar. Öte yandan İstanbul Hükûmeti işgal ve mütareke döneminde memleketin her tarafında iyice yaygınlaşan fuhşu denetim altına alabilmek için birtakım önleyici müdahalelere başvurur. Bu çerçevede hayat kadınları ve umumhanelerle ilgili çeşitli mevzuatlar çıkarılır; fakirlik yüzünden fuhşa sürüklenen kadınlara mesleki eğitim olanaklarının sağlanması yanında hayat kadınlarının hapis ve sürgün cezasına mahkûm edilmesi ya da sınır dışı edilmesi gibi cezalar da devreye sokulur (Yakut \& Yetkin 2011).

"Yatık Emine" adlı hikâyede anlatının merkezi kişisi "uygunsuz takımından" (1918a, 78) Emine'nin mülki amirlerin kararı ile ikamet yerinin değiştirildiğine tanık olunur. Hikâyenin anlatma zamanı 1918 olduğuna göre 1904 doğumlu olan Emine'nin (1918a, 79) on dört, on beş yaşında olduğu sonucuna ulaşılabilir. Kendisinden dolayı erkeklerin birbirini vurması ve evliliklerin boşanmalarla neticelenmesi yüzünden Ankara'dan uzaklaştırılan (1918a, 80) Emine'nin tek başına sürgün edilmesi önemli bir husustur. Çünkü sürgün cezası uygulamalarında, bekâr hayat kadınlarının babaları ve aile üyeleriyle birlikte, evli olanların ise kocaları ve çocukları ile sürgün edildiği bilinmektedir (Kırlı 2010, 45). Bu tarihsel bilgi, Emine'nin küçük yaşta olmasının yanında kimsesiz bir kadın olduğuna işaret eder ve yaptığı işte yalnızlığının, kimsesizliğinin de rolünün olabileceğini sezdirir. Ayrıca kâğıdına yanlışlıkla "Yatık Emine" yerine "Yanık Emine"nin yazılması (1918a, 79) onun vesikalı hayat kadınlarından olabileceğini düşündürür. Çünkü bu isim, karakterine bağlı olarak zamanla aldığı bir lakaptır. Anlatı tüm kasabaya karşı tek başına olan / kalan Emine'nin trajedisine odaklanırken o ve kasabanın amirleri ve ahalisi arasında gelişen yahut da en baştan itibaren var olan psikolojik, ahlaki ve fiziksel mesafeyi gözler önüne serer. Bu kapanamaz mesafeyi, devletin mercileri ve halkın yaklaşımları açısından ayrıntılı bir şekilde görünür kılmak mümkündür. 


\section{Devletin Temsil Güçleri: Karakol ve Kaymakamlık}

Hikâyede 1slah edilmesi maksadıyla sürgün edildiği kasabada Yatık Emine, ilk önce jandarma bölük kumandanlığının önüne getirilir. "Arkasında rengi atmış bir siyah yün çarşaf, yazma peçesi inik, elleri pelerinin altında saklı ufak tefek, mahcup ve korkak bir kadın"ı karşısında bulan Mülazım Dal Sabri şaşırır. Çünkü o, İstanbul sokaklarında bazen neferlerle rast geldiği gibi sigarası parmaklarında, allıkları yüzünde, peçesi açık, dişleri çürük, yürüyüşü kıvrımlı, tıknaz ve "yayvan yayvan" konuşan bir kadının karşısına çıkacağını ve kısa bir süre sonra da onu "jandarmalar"la tutturup "dışarı attıraca" ğını zanneder (1918a, 79). Bu durum gayri insanileştirmenin ortaya çıkmasında temel etkenlerden biri olan kalıp yargılarla ilişkilendirilebilir (Prati et al. 2015, 801). Mülazım'ın tahayyülündeki hayat kadını imgesinden farklı olarak son derece sıradan ve silik bir görüntü çizen Emine şaşkınlık uyandırır. Ancak bu kafa karışıklığı kısa bir süre sonra yerini şiddetin çeşitli biçimlerine bırakır ve Mülazım, Emine'nin kendisini tanıttığı, kâğıdına adının yanlışlıkla "Yanık Emine" olarak yazıldığını belirttiği sırada sözünü keserek şunları söyler:

Bana bak dedi, Yatık Emine misin, Yanık Emine mi, her ne herze ise, bana onun lüzumu yok; burası Ankara değil, aklını başına al, uslu otur, yoksa ufak bir münasebetsizliğini duyarsam seni karakola çeker, eşek sudan gelinceye kadar döverim, kemiklerin kırılır anladın mı? Şimdi arş (1918a, 79)!

Adının ne olduğunun bir önemi olmayan Emine'nin bir "münasebetsizlik" yapma ihtimali üzerinden onu "eşek sudan gelinceye kadar döv"ebileceğini söyleyen Mülazım Sabri, muhatabına insani bir muameleyi layık görmediğini en baştan hissettirir. Ayrıca Emine'nin isminin önemsenmemesi, değiştirilmesi ya da yok sayılması, insanlıktan men edilen bir birey olarak varlığının yadsınmasına karşılık gelebilmektedir. İç konuşma ile "İyi mal olsa buraya gönderirler miydi? Kavruk murdarın biri." (1918a, 79) dediğine tanık olunan Mülazım'ın aynı zamanda Emine'yi "mal" kategorisine indirgeyerek şeyleştirdiği izlenir. Gözlemci anlatıcı, Mülazım'ın sert tepkisi karşısında Emine'nin durumunu "Kadın hiç cevap vermedi; ezile büzüle, sıska bir yavru köpek gibi duvara, kapının pervazına sürtünerek dı̧̧arı çıktı." (1918a, 79) şeklinde tasvir eder. Tıpkı Emine'ye karşı gayri insani muamelede bulunanlar gibi anlatıcı da onun davranışlarını "yavru bir köpek"e benzetir. Hikâye kişilerinin kendilerinden kaynaklı saldırgan tutumlarının yanında anlatıcının Emine'nin korkulu ve çaresiz hâlinden hareketle yaptığı bu benzetme; her hâlükârda Emine'nin diğerlerinden ayrı bir kategoride değerlendirildiğine işaret eder.

Devleti temsil eden Mülazım gibi Kaymakam'ın da Emine'ye karşı tutumu, gayri insanileştirici özellikler taşır. Kasabada hiç kimsenin ev vermediği Emine'nin hapishanede kalmasına karar verilir; ancak oradaki iki mahpus, hapishane bahçesindeki dutlara ortak olan Emine'yi "hiç yoktan kavga çıkar"arak "bir iyi döv"erler. Bunu haber alan Kaymakam, "Haspa orada rahat durmamış" şeklinde tepkisini göstererek onun hapishanede öldürülmesinden ve bundan mesul tutulmaktan korkarak çıkarılması emrini verir (1918a, 80). Emine'nin mağduriyetini ve masumluğunu göz ardı ederek sadece kişisel menfaatlerinin zarar görebileceği endişesiyle hareket eden Kaymakam, "haspa" olarak nitelendirdiği Emine'nin sorumluluğundan kurtulmak ister. En sonunda kalem odacılarından bir ihtiyar "sokak ortasında kal"an Emine'yi evinde misafir etmeye razı olur. Ancak bir gün eşinin yokluğunda "hiç âdeti olmadiğı hâlde" evine giden odacının bu hareketi, Emine için o evdeki varlığının sonu anlamına gelir. Odacının karısı ve komşular tarafından dövülerek evden atılan Emine'nin durumunu öğrenen ve "hapishanede ölmesine razı olmayan" (!) Kaymakam'ın şu hâlde söylediği sözler; "Geberseydi de kurtulsaydık!' olur (1918a, 80). Emine'ye karşı çözüm arayışında samimi olmadığının ironik bir dille ortaya konulduğu Kaymakam'ın tutumu, nazarında Emine'nin telef edilmesi lazım gelen bir hayvan gibi göründüğüne ve ona karşı vicdani bir sorumluluk hissetmediğine işaret eder. 
Dayak yiyen ve sokakta kalan Emine'nin bir hastanede kalmasına karar verilmesiyle bir jandarma "kımıldanmaya mecali olmayan Emine'yi ite, söve önüne kat"ar ve şehrin dışındaki hastaneye götürür. "Yolda iki defa düş"en Emine, "jandarmanın akıl almaz bir ahlaksızlkkla şurasına burasına attığ çizmelerin altında, kamçı zoruyla kalkan bir lagar at gibi burnundan korkunç sesler çıkarıp soluyarak kendini top"lar (1918a, 80). Yine devletin yetkili bir merciini temsil eden bir kişi tarafından Emine'nin insanlık dışı davranışlara maruz kaldığ izlenir. Anlatıcının olanları "akıl almaz bir ahlaksızlık" olarak nitelemesi; bu vakadaki şahsi tutumunu gösterir. Söz konusu davranışları onaylamadığını hissettiren anlatıcının, Emine'nin gördüğü şiddet karşısındaki durumunu yine bir hayvan üzerinden somutlaştırması önemlidir. Tasvirî bir anlatım üzerinden Emine'nin "kamçı zoruyla kalkan" ve "korkunç sesler" çıkaran cılız bir ata benzetilmesi, şiddete uğrayan kimsenin, buna başvuran kişinin zihnindeki hayvani imgeye nasıl dönüştürülebildiğini göstermesi açısından dikkate değerdir. Bir mülazımın karşısında "sıska bir yavru köpek" gibi olan Emine, bir jandarmanın tekmelerinin altında "bir lagar at"a dönüşür. Değişen unvanlar şiddetin derecesini ifade etmekten öteye gitmezken Emine'nin içinden geçtiği her bir aşama önceki hâlinden daha kötü bir seviyeye evrilir.

Emine, gönderildiği bu hastanede nispeten biraz daha rahat eder. Fakat Mülazım Sabri, onun gardiyan Gürcü Server'le arasında bir ilişki olabileceğini duyunca kıskançlık duygusuyla hareket ederek hastaneden çıkarılması için Kaymakam'a bir müzekkere verir. Kaymakam da hastane memuruna; "Ankara'dan gelme bir kadın vardl; jandarma dairesi ona bir ev bulmuş, artık hastanede kalması caiz değil; elin aşüftesini biz mi besleyeceğiz; onu gönderin de yerine ehli namus bir başkasını istihdam edin!" şeklinde emir verir (1918b, 99). Bu şekilde Emine'nin hastanede emek vererek çalışmasının uygun bulunmadığına ve kamusal alanda olmayı hak etmediğine karar verilir. Bir taraftan gayri ahlaki şeylerden uzak durulması yasaklanan Emine'nin diğer taraftan ahlakını koruyarak ekmeğini kazanmasının uygun görülmemesi ironik bir durum oluşturur. Gayri insanileştirmeye dönük eylemlerin pek çoğunun hedef alınan kişinin kendine olan saygısını ve insanlığını yitirmesini (Çevik-Ersaydı 2011, 205) hedeflediği gibi Emine'ye de âdeta geçmişteki suçlarının bedelini "namus"lu kişilerin çalışabileceği işlerden uzak tutulması aracılığıyla ödetildiği fark edilir.

Erkeklerin özellikle cinsel açıdan çekime girdikleri için cinsellikleri ile ön plana çıkan kadınları gayri insanileştirme eğiliminde olabildikleri görülür (Vaes et al. 2011, 774). Emine'nin hastaneden kovularak boş bir eve atılmasındaki temel müsebbip de bir erkektir; Mülazım Sabri'dir. 'Sabri, âdeta hoşlandı̆̆ Emine'ye için için kızgındl; gözlerini unutamıyordu; fakat o kadar seviyesi düşük, adi bir kadındı ki elini sürebilmesine imkân yoktu; işte bu imkânsızlık onu böyle hain ve hasut ediyordu" (1918b, 100). Anlatıcının kișisel yargılarıyla birlikte verdiği bu iç çözümleme ile Mülazım için Emine'den etkilenmenin erkeklik gururunu ve bununla doğrudan ilgili olan toplumsal itibarını küçük düşüren bir vaziyet olduğu anlaşılır. Kişisel zaaflarını işine karıştıran Mülazım, Emine'nin Gürcü Server'le birlikte olduğunu duymasıyla da "Kahpe bize de göz yumdurttu be, hele bir payını vereyim!" diye Emine'yi çağırtarak döver. Anlatıcı onun bu eylemini "Her vuruşta biraz daha sakinleșiyor, âdeta

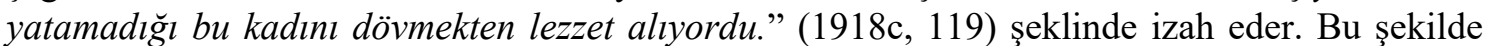
Mülazım'ın yön değiştiren davranışlarının geri planında onun haz nesnesine karşı duyduğu hasedin etkisiyle saldırganlaştığı anlaşılır. Ayrıca onun Emine'ye karşı duyguları, davranışlarında sıklıkla çelişsiye düșmesine yol açar ve kısa süreli yakınlașma hareketleri, bir süre sonra yerini mesafe ve saldırganlığa bırakır. Bir aralık "kendi tayınından günde bir ekmek verilmek üzere firıncıya emir gönder"en Mülazım, firıncının "Paşam (...) affet, o kötü karıya ben artık ekmek mekmek veremem." şikâyeti üzerine "Kes (...) gebersin kahpe!" (1918c, 120) diyerek ötekileştirilen kişinin ölümüne karar verecek noktaya kadar gelinebileceğini gösterir. Mülazım'ın "kahpe", fırıncının "kötü karl" dediği Emine, tüm taraflarca bir nefret nesnesi olarak yaşamını sürdürmek zorunda kalır ve Gürcü Server'in de uzak bir yere gönderilmesiyle 
özellikle maddi açıdan tam anlamıyla çaresizlik içinde kalır.

Hikâyenin Emine açısından en trajik noktalarından biri yeni polis olmuş genç bir çocuğun Emine'ye sadaka verme hazırlığı içindeyken bir komiserin "gözleri dönmüş" hâlde bunu engellemesidir (1918c, 119-120). Bunun üzerine "gözlerini çevir"ip "içinden on beş senelik musibetlerin hazmedilememiş acısı taşan bir bakışla komiseri uzun tetkik" eden Emine, "yine bir şey demeden aç bir kurt gibi atılıp ısırması iktiza eden bu vücuda karşı hâlâ isyan etmek arzusu duymadan salına salına hükûmet avlusundan çıkı" gider (1918c, 120). Emine'nin sadece uzun bir bakışla tepkisini belli etmesi karşısında anlatıcının araya girerek kendi düşüncesini doğrudan belirtme ihtiyacı duyması önemli bir noktadır. Emine'nin "aç bir kurt gibi atılıp ısırması" gerektiğini belirten anlatıcının, Emine'yle ilgili bir tasvirde yine bir hayvana ait kelime grubunu kullandığı; ancak burada olanı değil, olması gerekene işaret ettiği görülür. Aç bir kurda dönüştürülen, buna dönüşmesi için türlü yollara başvurulan Emine'nin kendisine gayri insani muamelelerde bulunanlara hak ettikleri nispette karşılık vermesi gerektiği açıkça belirtilir. Bu tutum anlatıcı temsilinde, gayri insani muamelelere tanık olan (vicdani sorumluluğa sahip) kişilerin tepkisiz kalmaması gerektiğini hatırlatır / düşündürür gibidir.

\section{Kasaba Halkı: Kadınlar ve Erkekler}

Gayri insanileştirmeyi uygulayan gruplar kendilerini seçilmiş, ahlaki açıdan mükemmel ve diğerlerinden daha üstün konumda bulurlar (Çevik-Ersaydı 2011, 105; Bar-Tal 1989, 177-178). Anlatıda kasaba halkının Emine'yi dışlamasında da onun benimsenen / benimsendiği iddia edilen ortak değerlerin dışında görülmesi etkili olur. Öncelikle Emine'nin bu kasabaya sürgün edilmesi kasabanın “izzetinefsini yarala"r; ancak Kaymakam'a göre sevap yolundan sapan bu kadın, memleketlerinde ahlakını değiştirecek ve doğru yolu bulacaktır (1918a, 79-80). Kasabanın tepkisi ve Kaymakam'ın onları sakinleştirmek için verdiği cevap; onların kendilerini gayri insanileştirdikleri Emine'den daha temiz ve pak olarak gördüklerini hissettirir. Hatta eşrafın bazı nüfuzlu kimselerine göre "Burası namuslu bir kasabaydı, o karı açlıktan geberir, fakat kimseden yardım görmezdi; günahtı (...)" (1918c, 120) sözleri, onların üstünlüklerinin kaynağını göstermekte; yaptıkları gayri insani davranışların temelinde ahlaki bir ayrımın yattığına işaret etmektedir. Ayrıca bu ifadelerde dinî argümanların kullanılarak kişisel acımasızlıkların meşrulaştırıldığına da tanık olunur. Kaymakam'ın Emine'nin doğru yolu bulmasında kasabanın örneklik teşkil edebileceğini söylemesine karşın bunun eyleme dönüşmemesi de belirtilen sözün kendindeki gerçekliğinden ziyade barındırdığı üstünlük duygusunu daha fazla açığa çıkarır. Kasabadaki "ahali", Emine'ye "sert, merhametsiz davran"mayı (1918a, 80) anlatının sonuna kadar sürdürür.

Günlerdir aç kalan Emine, Mülazım Sabri’nin payından verilen ekmeği firıncının hileleri yüzünden bazen günlerce alamaz. Her seferinde ekmeği verdiğini söyleyen tablakârın sözlerine inanan etraftaki adamlar da "Hay çirkef hay, sıkılmasa firını götürecek!" diye ona arka çıkarlar. Bir gün açlığın şiddetiyle "tezgâhın üzerinden sıcak, beyaz bir okkalık yakala"yan Emine, bunu ortasından böler ve iri bir parçayı hemen ağzına atar. Anlatıcı, bundan sonra gelişen durumu; "Çıraklar koşuştular elinden almaya, ăgzındakini çıkarmaya uğraşıyorlar, boğuşuyorlardı." (1918c, 120) şeklinde tasvir eder. Burada hakkı olanı almasına rağmen ahali tarafından Emine'nin açgözlü, hırsız ve saldırgan olarak görüldüğü/yansıtıldığı izlenir. Özellikle ağzındaki lokmanın çıkarılmaya çalışılması; ötekinin hayvan imgesinden daha aşağı bir seviyede görüldüğüne, aşağılanmanın ileri boyutuna işaret eder.

Emine'nin hayat kadını kimliği; yeme, barınma başta olmak üzere temel ihtiyaçlarının karşılanması önünde büyük bir engeldir. İnsan olarak varlığ 1 yadsınan Emine'nin buna bağlı olarak vatandaş olarak da temel haklarından mahrum edildiği görülür. Evi soyulan Emine'nin şikâyeti ve durumuyla hiçbir yetkili ilgilenmez. Birlikte olduğu Gürcü Server'in desteğinden de mahrum kalan (1918c, 119) Emine'nin nasıl geçineceği konusu ne devletin ilgili mercilerini ne 
de kasaba halkını ilgilendirir:

Boş evde sıkıntılı bir gece geçirdi. (...) Fakat mülazım bir türlü gelmiyor, Emine de bu sefer büsbütün aç, çıplak firınlar, bakkallar önünde çarşıly kovula, sövüle dolaşlyor, bazen de bostanlarda, kırlarda yatıp kalklyordu. Ara sira sataşanlar oluyordu; açlıktan gözleri kararan bu mecalsiz, bitkin kadina sadaka vereceklerine laf atı geçiyorlar, gülüşüyorlardı (1918c, 119).

Ezen-ezilen arasındaki mesafenin derin boyutlara ulaştı̆̆ 1 bu anlatımda gayri insanileştirmenin aç bir insana yardım edilmeyecek noktaya kadar ulaştığı izlenir. Muhtaç birine yardım edilmemesi bir tarafa "kov"ma,"söv"me, "sataş"ma, "laf at"ma ve alayın mevzubahis olması düşmanca duyguların şiddetini göstermede önemlidir. Anlatıcının Emine'ye sadaka verilmesi gerektiğini belirtmesi ise bu olanlar karşısında olması gereken insani değeri ortaya koyar. Mülazım Sabri'nin onu "kötü karı", kasaba halkının "çirkef" olarak isimlendirmesinin aksine anlatıcının "mecalsiz, bitkin kadın" adlandırması, Emine'ye olan bakışta benimsenen farklı tutumları belirgin k1lar.

Genel olarak toplumun birçok kesimi tarafindan ötekileştirilen Emine, özellikle namuslu kadınlar için bir rakip, tehdit olarak konumlanır. Toplumsal güzellik normlarını içselleştirmiş ve özellikle erkeklere çekici görünme arzusu taşıyan kadınların cinsellikleri ile ön plana çıkan hemcinslerini gayri insanileştirme eğiliminde olduğu görülür (Puvia \& Vaes 2013, 484). Benzer bir davranışsal örüntüyü kasabalı kadınların Emine'ye karşı yaklaşımlarından da sezinlemek mümkündür. Ankara'da kendisi yüzünden birçok olayın çıtı̆̆ı Emine, kasabadaki kadınların evliliği için açık bir tehlike; çoğu kez de olumsuz anlamda insan dışı bir varlık olarak düşünülür. Hapishaneden dövülüp kalem odacılarından birinin evinde kalan Emine'yi görmek isteyen kadınlar, kafileler hâlinde odacının evini ziyaret eder. "Ev dolup dolup boşa"lır, "bir dü̈̆üne gelir gibi feslerine inci, boyunlarına beşibiryerde takmış, yüzlerine düzgünler sürmüş iri, kuvvetli ve bu yeni dişiye karşı kıskanç kadınlar arasında Yatık Emine şakağındaki taze yarası, sol ayağına topallık veren beresi ile dolaşı"r, "kovulmamak, dışarı atılmamak için her şeye razl, kendini seyrettiri"r (1918a, 80). Emine karşısında kendi çekiciliklerini ön plana çıkarmak isteyen kadınların onu seyirlik nesneye dönüştürmesindeki motivasyon doğrudan "kıskanç"lık olarak belirtilir. Emine'nin erkekler üzerindeki etkisine bir anlam veremeyen kasaba kadınları, onu yine insan olmadığı anlamına gelecek şekilde "kara gözlü büyücü kadın" (1918a, 80) olarak anar. Bu şekilde Emine'yi insan dışı bir varlık olarak kendilerinden uzak hatta "kara"nlık bir dünyaya ait varsayarak kendi insaniliklerini pekiştirmiş olurlar.

Kasabanın kadınları için öteki olan Emine'yi yakından görebilmek, onu tanımak önemlidir. Ancak bu tanıma insani anlamda yakın olma çabasından kaynaklanmaz, merakın sonucunda gelişir. Kıskançlığın etkisiyle kadınların "bir düğüne gelir gibi” süslenerek gelmesi, Emine'nin duyulan ünü karşısında hissedilen aşağılık kompleksini telafi etme çabası olarak da okunabilir. Vaes ve arkadaşları $(2011,774)$ tarafından yürütülen bir çalışmada, kadınların cinselliğiyle ön plana çıkan kadınlara benzemekten kaçınmak için hemcinslerini gayri insanileştirdikleri ortaya koyulur. Buna paralel olarak kasabalı kadınların Emine'nin içinde bulunduğu hâl ile tezatlık oluşturacak şekilde giyinip kuşanmaları da kendileri ile Emine arasındaki sınırı keskinleştirme / belirginleştirme arzularının bir yansıması olarak dikkat çeker. Emine ise kendi iradesi dışındaki bu olayları sessizlikle kabullenerek birincil ihtiyacı olan barınma imkânını korumak ister. Ancak bir gün kocasını kıskanan odacının eşi ve ona yardım eden komşuları tarafından kaldığı evden "bir bohça gibi dışarı firlatıl"1r. Ona "sanki bu sessiz, hareketsiz vücut onları ısırıyor, sokuyormuş gibi korka korka haykırışarak mütemadiyen nalınlı ayaklarıyla vuruşturu"rlar (1918a, 80). Odacının evindeki varoluşu, merak nesnesi olmasına bağlı olan Emine'nin bu evdeki hikâyesinin "bir bohça gibi" fırlatılarak sonuçlanması, belirtilen hareketin kolay oluşu ve beraberinde 
herhangi bir sorumluluk getirmemesiyle ilgilidir. Cansız bir nesnenin akıbeti söz konusuymuş gibi son derece hissiz muamelelere layık görülen Emine'nin dövülme sahnesinde ise kendisine âdeta bir yılan gibi davranıldığı ifade edilir. Onun bir hayvan gibi düşünülmesi, ondan kendini koruma hakkını beraberinde getirdiği gibi onu tehlikeli görülen zamanlarda "vur"ma hatta yok etme hakkını da kişiye verir. Anlatıcının hayvanlar üzerinden yaptığı bu tasvirler, Emine'nin etrafındaki kişilerin zihninde karşılık bulduğu imgeyi daha da belirginleştirir.

Emine'nin kasabadaki erkekler tarafından gördüğ̈̈ muameleler de kadınlardan pek farklı değildir. Ancak erkeklerin ötekileştirilmesinde farklı motivasyonlar devreye girmekte; öncelikle Emine'nin arzu nesnesi olarak elde edilememesinin erkeklerde öfke ve şiddete yol açtığ 1 görülmektedir. Kadınları ilkellikle ya da cansız objelerle eş tutan erkeklerin kadınlardan cinsel anlamda yararlanma istekleri daha fazladır (Rudman \& Mescher 2012, 734). Dolayısıyla kadınları hayvani ya da mekanik bir temsil üzerinden insan dışı varlıklarla ilişkilendiren erkeklerin, kadınlara karşı cinsel saldırganlık sergileme ihtimalleri artmaktadır. Anlatıda da ulaşılamayan yahut başkaları tarafından ulaşılan bir arzu nesnesi olan Emine, erkeklerde yoğun bir haset duygusu uyandırır ve bu da onun değersizleştirilmesine ya da insanlıktan çıkarılmasına yol açar. Bir tapu memurunun arkadaşlarıyla sohbet sırasında Merkez Komiseri Hacı Bekir Efendi'nin kendisine "Git de gözü onda gör, adamın yüreğini gicıkllyor!” (1918b, 99) şeklindeki sözlerini aktarması, bunu belirten kişi(ler) dâhil bu sohbete katılan devlet memurlarının genel fikrini ortaya koyar. Gürcü Server'le birlikte olan Emine'nin başkalarına karşı "aldırma" $\mathrm{z}$ tutumu ise erkekleri daha fazla çileden çıkarır ve böyle durumlarda o, "kafasına kasatura" indirilmesi lazım gelen biri olarak tarif edilir. Hatta Server dışında hiç kimseyle birlikte olmadığı hâlde evine başkalarını aldığ 1 dedikodusu çıkartılır (1918c, 119).

Özellikle Emine'nin evine gitmesini “aleniyete vuran Server'e düşmanlar"1n "peyda ol"ması, ulaşılamayan arzu nesnesinin bir başkası tarafindan ele geçmesi karşısında duyulan hasedi arttırır. Gürcü Server'in Emine ile ilişkisini öğrenen bir çavuşun “(...) bir gece Server çekilip gittikten sonra, yüreğindeki kıskançlı̆gın arttı̆̆ını duy"arak yanındaki arkadaşına "Hele ettiğine bak Gürcünün... Bizi, çağırsa ya!.." (1918c, 119) şeklindeki sözleri, dışarıda tutulmuş olmanın getirdiği hıncı ortaya koyar. Bu öfkeyle bölük eminine haber veren çavuş ve arkadaşı, Server'in köprü muhafizlığıyla iki günlük uzağa "atıl"masını sağlar (1918c, 119). Bu sayede kendileri için tehdit olarak gördükleri bir rakibi ortadan kaldırırlar.

Server'in evvelce yattığ ayının "sert bir gece"sinde uygulamaya konulur. "Doğruca gidip kapıyı çalsalar sanki ne lazım gelirdi? Gürcü'nün girdiği gibi bunlar da girerlerdi, elin kahpesi, ne demeye hakkl vardl?" (1918c, 120) kararıyla Emine'nin evine giderler. Onlara göre bir hayat kadının kendisiyle beraber olacağı kişiyi seçme hakkı yoktur. Haneye tecavüz ederek Emine'nin evine giren bu iki arkadaş, şöyle bir manzara ile karşılaşır:

Yatık Emine açliktan ve soğuktan öleli galiba günler geçmişti. Tüh, bu ne aksi işti... Nefer de, daha ziyade sağlam tutmak için, bir defa yokladı:

- Yetişemedik be, gebermiş!..

Dedi. Bir müddet, en deni iki hayvan gibi zihinlerinden fena şeyler geçirerek durdular. Sonra "Haydi, gidek!" ikazlyla birbirlerini iterek gecenin karlı rüzgârlarına karışıp küfür ede ede uzaklaştılar (1918c, 120).

Ölen bir kadınının bedeninden yararlanma düşüncesinin görüldüğ̈ bu trajik sonda gayri insanileştirmenin vardığı son noktaya tanık olunur. Emine kasaba halkının söylediği gibi açlıktan "geber"miş, ama kimseden yardım görmemiştir. Hikâyede Emine hakkında en sık kullanılan fiilin "geber"mek olması tesadüfi değildir. Ölmek anlamına gelen gebermek; sevilmeyen kimseler ve hayvanlar için kullanılan ve hakaret anlamı taşıyan bir sözcüktür 
(Kubbealtı Lugatı n.d.). Emine'nin varlığı ve yokluğu karşısında gebermesine yönelik istek, ona bir insan olarak yaşama hakkı tanımayan insanlık dışı arzuların içselleştirilmesiyle ilgili olsa gerektir. Anlatıcının Emine'ye bir hayvan gibi davrananların aslında ne olduğuna dair fikrini doğrudan ifade eden "en deni iki hayvan gibi" edat grubu ise okuyucusuna durduğu yeri göstermesi açısından anlamlıdır.

Kasabanın erkekleri içinde Gürcü Server'in ve bir süre için de olsa bir arzuhalcinin Emine'ye yaklaşımının ayrı bir yerde durduğunu ayrıca belirtmek gerekir. Anlatıda Gürcü Server ile Emine birbirinden hoşlandıkları için birlikte olur. Gürcü Server, kasabadan ayrılmak zorunda bırakıldığı ana kadar Emine'nin yemek, barınma, giyinme, temizlik, süslenme gibi ihtiyaçlarını "iyi" (1918c, 119) bir şekilde karşılamaya çalışır. Anlatıcının sadece ondan "yiğit bir adam" (1918b, 100) olarak sitayişle bahsetmesi nedensiz değildir. O, davranışsal göstergeler bakımından anlatıdaki diğer erkeklerden ayrışır. Arzuhalcinin anlatıdaki konumunun ise ikircikli olduğu söylenebilir. Zor durumda olan Emine, devletin ilgili makamlarına durumunu belirten bir dilekçe yazmak için arzuhalcilerin kapısını aşındırır. Fakat ona ücreti karşıllı̆ında dilekçe yazmayı kabul eden tek kişi, "reji kantarcıllı̆ından kovulmuş serseri ve yarı meczup bir adam" olur. Aç kalan Emine'nin durumuna üzülen bu arzuhalci, Emine'nin "Dört gündür sıcak yemek yemedim, günah değil mi, beni buraya gönderdilerse açlıktan ölsün demediler a; Ankara'da hiç olmazsa karnım doyardl... Gözlerim kararlyor!" demesi üzerine "uzun bir arzuhal" yazar. Emine parasını vermek istese de kabul etmeyen arzuhalci ona "Sende kalsin, kebap ye!" der. Anlatıda bu durum; "Iki serseri bu merhamet hissiyle birbirlerine ne kadar yaklaşmışlardı...” (1918b, 100) şeklinde belirtilir. Biri serseriliğinden diğeri işinden dolayı toplumun genel kabullerine aykırı olan bu iki kişiyi, insani bir duygu olan merhamet yakınlaştırır.

Arzuhalcinin Emine'nin içinde bulunduğu durumu, gerçekçi bir bakış açısıyla yorumlaması da hikâyenin âdeta iletisini sunar: "Bunlarda akıllıca iş arama... Seni sürerler, nasıl geçineceğini düşünmezler; açlık bu, ne yapacaksın ya, yine önüne gelenle düşüp kalkacaksın" (1918b, 100)... $\mathrm{Bu}$ anlamda arzuhalcinin ifadeleri üzerinden bir hayat kadını olan Emine'nin bu işi bırakmasını sağlayacak çözümün ona geçineceği bir iş bulmakla mümkün olduğuna işaret edilir. Emine'nin durumu için söz konusu farkındalığa sahip tek kişinin "serseri ve yarı meczup" biri olmasının metaforik karş1lığ 1 üzerinde de durmak gerekir. Aslan-Ayar'a (2017, 78-79) göre Emine gibi kadınlar yargılayıcı, dışlayıcı ve damgalayıcı ataerkil bakışa "gönüllü uyum sağlayanlar, genele göre yaşayan, "normal"in belirlenmiș tanımını kabul eden ve bu anlamda da toplumsal üst akılla ters düşmeyip rahat biçimde yaşayanlardır". Arzuhalciyi ise toplumsal dayatılara karșı durmasıyla hikâyenin en güçlü ve kendini özgür kılabilmiş tek öznesi olarak ifade eden AslanAyar, onun başkalarının bakışında nasıl göründüğünü önemsemediğini ve bakışını kendi bireysel ahlakı üzerinden belirlediğini ifade eder. Ancak bu tespitte Emine'ye bir zaman için hakkaniyetli davranan hatta bir keresinde ağzından lokması alınmaya çalıșırken onu kurtaran $(1918 c, 120)$ bu arzuhalcinin davranışlarındaki süreksizliğin göz ardı edildiği görülür. Zira arzuhalci, Emine'nin kendisine derdini anlattığı bir gün yazıhanenin camekânından kendisini "seyred"enleri görmesiyle Emine'yi omuzlarından tutup bacağının olanca kuvvetiyle "arkasına bir tekme vur"arak atması bir olur. "Belalı karı" olarak düşündüğü Emine yüzünden "maskara ola"bilme korkusu (1918c, 119) vicdani değerlerinden ağır basar. Arzuhalcinin gayri insanileştirici muamelesi, Emine gibi bir kadının toplumun hiçbir kesiminde yer bulamadığının göstergesi olarak okunabilir. Bir yarı meczubun dahi böylesi bir konuda toplumun kalıp yargılarından kaçamadığı ve onların nazarındaki konumunun sarsılabileceğinden endişe ettiği fark edilir.

\section{Gayri İnsanileştirmeye Maruz Kalan Taraf: Yatık Emine}

Gayri insanileştirilen kişi ya da gruplar maruz kaldıkları toplumsal dışlanma sonucunda 
kendilerini hedef alan insanlık dışı tutum ve tavırları içselleştirmekte hem kendilerini hem de onları dışlayanları "daha az insan" olarak algılamaya yönelebilmektedir (Bastian \& Haslam 2010, 107). Sosyal bağl1lıklar zedelendiğinde, dişlanan kişinin diğerleriyle paylaştı̆ğ ortak insanlık zemini kayganlaşmakta ve dışlanan kişi hem kendisinin hem de onu dışlayanların insan doğasına has özelliklere daha az sahip olduğunu dile getirmeye başlamaktadır. Bu noktada toplumsal dışlanmayı gerçekleştiren kişiler için kullanılan taş kalpli, kalpsiz, merhametsiz gibi sıfatlar aslında dışlananlar kadar dışlayanların da insaniyetlerinin (insan oluşlarının) sorguland1ğını ortaya koyar (Bastian \& Haslam 2010, 107). Peki, resmî kayıtlarda adı yanlış yazılan, devleti temsil eden kişiler ve halkın nazarında "haspa"; "Ankara'dan gelme bir kadın", "elin aşüftesi”, "kahpe", "kötü karı", "belalı karı", "çirkef" ve "Yatık” olarak anılan Emine, bu gayri insani muameleler karşısında kendisini ve diğerlerini nasıl tanımlar? Başkalarının algıları ve kararları Emine'nin karakterini, kaderini nasıl belirler ve Emine, kendisi hakkındaki bu algıları ve davranışları ne kadar içselleştirir?

Diğerlerinin Emine'nin kişisel algısından önce hayatı üzerinde yol açtığı etkiyi belirginleştirerek bu sorulara bir cevap arayışına girilebilir. Gayri insanileştirmede ötekileştirilen kişi ya da kişiler bizin dünyasından uzaklaştırılır; böylece iğrenilen ve nefret edilen insan dışı varlıklara karşı hem psikolojik hem fiziksel bir mesafe konulması hedeflenir (Haslam \& Loughnan 2014, 415). Benzer şekilde, söz konusu hikâyede de hep istenmeyen taraf olan Emine'nin anlatı boyunca sıklıkla bir yerden bir yere sürüklendiği görülür. Emine için çok hareketli bir seyir izleyen mekânsal değişimleri Fig 1'deki gibi göstermek mümkündür.

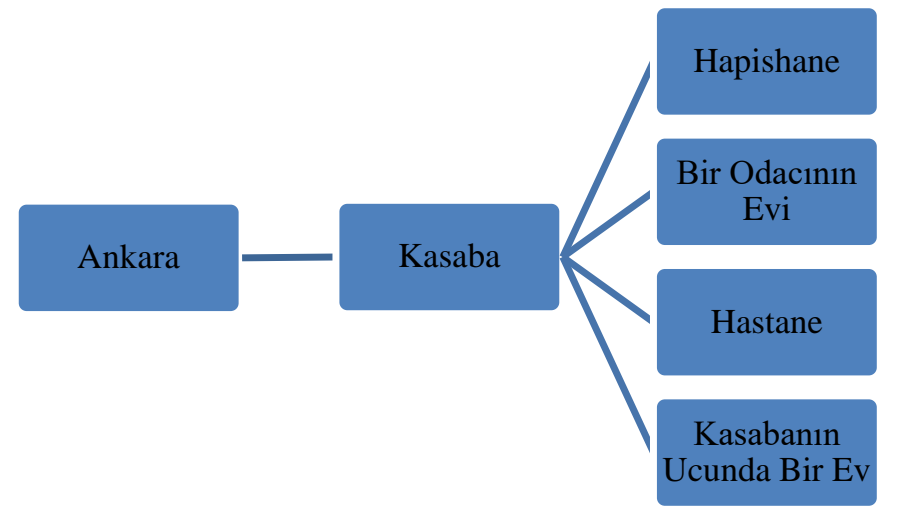

Fig. 1. Emine'nin Sürgün Edildiği Mekânlar

Anlatıda Emine ilk önce Ankara'dan sürgün edilir. Gönderildiği mekân Haymana Ovası'nın ortasında "soğuk, barınılmaz bir kışı, susuz, dayanılmaz bir yazı" olan içinde "oturulacak bir kahve, yatacak bir han bulunma"yan ücra bir kasabadır. "Civara nispetle o kadar yolsuz ve yüksek" olan kasabanın coğrafik konumu, doğa koşulları, özellikle kahve, han gibi dışarıdan gelen insanların kaynaşmasına imkân verecek alanlardan mahrum oluşu ve "zevksiz" ve "kasvetli" (1918a, 79) hâli, içinde bulunulan mekâna uygun olarak insanların da karamsar ve tekdüze bir yaşam içinde olabileceğini sezdirir. Ayrıca kasabanın bu şekilde tasviri; türlü insanlık hâllerine şahit olamadığı için daralan ve gittikçe tutucu bir yapı kazanan ahalisinin perspektifine işaret etmesi açısından işlevseldir. Ötekinin sıklıkla ortada bırakıldığı, dışlandığ 1 durumlarda olduğu gibi Emine de gönderildiği bu kendi içine dönük kasabada sürekli olarak var olan mekânların dışına itilir. Kalacak bir yeri olmadığı için geçici olarak hapishanede kalan Emine, burada iki kadın mahkûm tarafindan dövüldükten sonra kalem odacılarından birinin evinde alıkoymasına "razı ol"masıyla bir eve sığınır. Ancak orada da yine kadınlardan dayak yiyerek ve onların "at dışarı" (1918a, 80) sözleri eşliğinde sokağa atılır. Her iki durumda da masum olması "dışarı" atılmasına engel olmaz. Eczanenin kapısının önünde inleye inleye sekiz saat bekleyen Emine'nin yaralarını, ihtiyar Rum eczacı parasını alamayacağı için yıkayıp 
sarmaz. Genç kadın kaymakamlığın emriyle şehrin "dışı"ndaki hapishaneye gönderilir ve iki saat önce içinde ölü yatan temizlenmemiş bir yatakta yatırılır $(1918 \mathrm{a}, 80)$. Orada bir hademe kadının yerine hastanede çalışan Emine, "yerlerde sürüklenmeden, hırpalanmadan" karnını doyurduğu bu mekândan da kısa bir süre sonra "attırı"larak kasabanın "ucu"nda, Tatar muhacirlere ayrılmış "ücra" mahallenin "en izbe bir köşesinde"ki (1918b, 99) bir eve taşınmak zorunda birakilır.

İçinde ne minderi ne şiltesi ne de perdesi olan bu bomboş evde Emine'nin nasıl yaşayacağ hayati bir mesele olarak belirir. Bu süreçte Emine ile birlikte olan ve onun tüm ihtiyaçlarını karşılayan Gürcü Server, onun hamamdan başka "dışarıya çıkmasını" yasaklar. Bu birliktelik döneminde "bohçasını hazırlayıp sik sık hamama" giden Emine, "bir koca kalıp sabunla yıkandiğını, fildişi tarakla tarandığını gören kadınları kıskandır"ır. Server'in uzak bir yere gönderilmesinden sonra ise iyice sahipsiz kalan Emine'nin evindeki her şey Tatar kadınları tarafından çalınır. Bu durumla karşılaştığı zaman ise "canını" en çok "yak"an fildişi tarağın aşırılması olur (1918c, 119). Fildişi tarak, Emine'nin kendisini değersizleştiren kişilere, en çok da kadınlara karşı kendisinin de bir kadın, değerli bir varlık olduğunu gösteren sembolik bir unsur olarak belirir. Ancak kısa bir süre sonra elinden çıkan bu parça, onun diğer insanlar gibi hissetmesine/yaşamasına izin vermeyen düzenin bir başka şiddeti olarak anlatıda yer bulur.

Emine'nin kendisine karşı gayri insani muamelelerde bulunan kişilerin algısını çoğunlukla içselleştirmediği, kendisine olan saygısını yitirmediği söylenebilir. Server'in severek birlikte olduğu ve Mülazım Sabri'nin hoşlandığı Emine, bir kadın olarak dikkat çektiğinin, beğenildiğinin bilincindedir. Ayrıca Emine'nin kasaba halkının ve devlet kurumlarında çalışanların kendisine hakaret ettiği sıfatlar üzerinden de kendisini değersizleştirmediği fark edilir. Fildişi tarakta olduğu gibi Emine, ilgiye değer bir kadın olduğunu, geçimi için karakola sürekli başvurmasında da insan olarak varlığının korunmayı hak ettiğini göstermiş olur. Ayrıca Emine'nin gördüğü şiddete karşın kimseye zarar vermeyi düşünmediği de fark edilir. Sıcak bir yer ve bir kap çorba onun memnun olması için yeterlidir $(1918 b, 100)$. Özgen'in $(2011,2003)$ belirttiği gibi Emine, altında ezilmekte olduğu tüm sıkıntılara, kasaba halkının taş kalpliliğine rağmen içinde sevgi taşıyan ve bu sevgisini, "A klz!" șeklindeki seslenișinde olduğu gibi samimiyetle yansıtan bir karakter olarak görünür. Ancak hikâyede bir gün Emine'nin Mülazım Sabri'den yediği dayağı "lezzetli" (1918c, 119) bulduğunun belirtilmesi, onun hoşlanma, âşı olma gibi duyguları kimi zaman insanca deneyimleyemediğinin bir ișareti olarak okunabilir.

Hikâyede Emine'nin sürgün edildiği kasabadan önceki hayatı hakkında pek bilgi verilmez. Onun bu işi niçin ve ne zamandır yaptığı bilinmemektedir. Hikâyede yer yer çekici bir kadın oluşunun farkında olduğu bilgisi verilen Emine'nin bu arzuları dolayısıyla $\mathrm{m}$ bu işe sürüklendiği bir soru işaretidir. Diğer yandan onun kimseyi arzuları için baştan çıkarmadığı, bir dönem birlikte olduğu Server'e de sadık kaldığı izlenir. Emine'nin "yatık" lakabı, bu durumun sebebini sezdirebilir. Anlatıcı Emine'nin başına gelen sıkıntılardan sonra "İşte bunun için, böyle her zora katlanıp her arzuya kapıldı̆̆ından, ne yapılsa şikâyetsiz, sızıltısız rıza gösterdiğinden dolayı Emine'ye, Yatık Emine derlerdi." (1918a, 80) açıklamasını yapar. Belki de Emine başına gelen, getirilen durumlara karşı sesini çıkaramadığından dolayı böyle bir hayatı seçmek zorunda bırakılmıştır. Anlatıda bununla ilgili tek bir izahın olmaması; belki de buna gerek duyulmaması, gayri insanileştirilmenin hiçbir haklı tarafının olamayacağıyla ilişkili olabilir. Ayrıca hikâyede "yatık" kelimesinin Emine'nin temsil ettiği sosyal grup için sembolik bir anlamı olabileceği de öne sürülebilir. Başına gelen türlü kötü olaylara rağmen hep boyun eğen Emine'nin sessizliği, toplumun bu kesiminin sessizlikten başka bir çaresinin olamamasının simgesi olarak yorumlanabilir. Emine'nin başının önünde olması, şikâyet etmemesi, genellikle söylenmemesi, başına gelen her şeyi kabul etmesi olarak değil kabul etmek zorunda kalması olarak okunabilir. Zira onun isyan ve itiraz etmeyen hâli, bu işi yapan kadınlar için hiçbir çözümün olmayışı / 
getirilmeyişi ile ilişkili olabilir.

\section{Sonuç}

Refik Halit Karay, "Yatık Emine" hikâyesi ile gayri insanileştirme olgusunu tarafların kişilik / mekânsal özellikleri ve acı verici sonuçları bağlamında tüm çıplaklığı ile gözler önüne serer. Bu şekilde gayri insanileştirilen kişilerin sadece toplumsal grup ve mekânlardan uzaklaştırılmadığ başta dil düzeyinde olmak üzere yok sayıldığı trajik bir şekilde ortaya konulur. Gayri insanileştirmeyi uygulayan kişi ya da kurumlar hedefteki kişinin insanlığını yok sayarken ironik bir şekilde kendileri de insanlıktan uzaklaşır. Bu hikâye, kötülüğün sanıldığı gibi şeytani güçlere sahip varlıkların elinden değil de sıradan insanın vicdanından (ya da vicdansızlığından) neşet ettiğini göstermesi bakımından oldukça vurucu bir niteliğe sahiptir. Düşmüş bir hayat kadınını ahlaki açıdan yola getirmek gibi ulvi bir görev üstlendiğine inanan kasaba halk1, insan addetmedikleri bu kişinin acısına, sefaletine ve ölümüne kayıtsız kalmış ve onun akıbeti hakkında herhangi bir sorumluluk almaktan kaçınmıştır. Ancak her kim olursa olsun birini göz göre göre ölüme terk etmek, ahlaki açıdan sorgulanması gereken bir davranış olarak anlatıda yer bulur.

Hikâye boyunca gayri insanileştirmenin şiddetinin artmasına karşılık buna maruz kalan tarafın mağduriyetinin ve sessizliğin artması, sınırın dışında kalanların akıbetinin anlaşılması adına dikkat çekici bir noktadır. Karay, (çoğu zaman) soğukkanlı bir üslupta işlediği olay merkezli anlatısı ile kimin insan olup kimin insan olmadığı arasındaki ince çizgiyi sorgulamaya açmak ister gibidir. Anlatıdaki mekân Türkiye'nin kasabalarından biri olsa da ele alınan konu, Anadolu insanından öte insanın kendisine odaklanmakta ve evrensel bir problem olan ötekileştirmenin boyutları üzerine düşündürmektedir. Karay, Yatık Emine karakteri ile hayat kadınının kendindeki kötücül niteliklerinden ziyade ona yöneltilen kötücül bakış ve tutumları merkeze alması itibarıyla insanlığın tevarüs edilen nitelikten fazlası olduğuna işaret eder. Bu bakımdan "Yatık Emine" hikâyesi, hayat kadınının hep yok sayılan ancak çok gerçek olan insan oluşuna, gayri insanileştirme üzerinden yaptığı vurgu ile edebiyat tarihimizde dikkat çekici bir yerde durur.

\section{Yazarın Notu}

Memleket Hikâyeleri'ni günümüz harflerine aktararak yayımlayan İnkılâp ve Aka Kitabevleri ile Semih Lûtfi Kitabevinden çıkan baskılarda "en deni iki hayvan gibi" ifadesinin geçmediği tespit edilmiştir. Hikâyenin 1919'da yayımlanan Memleket Hikâyeleri'ndeki ilk baskısında ise bu ifade korunmuş; fakat günümüz harflerine aktarımda yer yer sadeleştirmelere giden yayınevlerinden çıkan nüshalarda söz konusu kelime grubuna yer verilmediği görülmüştür. 


\section{KAYNAKÇA}

Aktaş Ş. (2004). Refik Halit Karay. Ankara 2004.

Aslan-Ayar P. (2017). "Refik Halit Karay’ın "Yatık Emine”sinde Görülen Ama Göremeyen". Edebiyat Fakültesi Dergisi 34/1 (2017) 71-80.

Bandura A. (1999). "Moral Disengagement in the Perpetration of Inhumanities". Personality and Social Psychology Review 3/3 (1999) 193-209. doi: 10.1207/s15327957pspr0303_3

Bar-Tal D. (1989). "Delegitimization: The Extreme Case of Stereotyping”. Eds. D. Bar-Tal, C. Grauman, A. Kruglanski \& W. Stroebe, Stereotyping and prejudice: Changing conceptions (1989) 169-188. New York.

Bastian B. \& Haslam N. (2010). "Excluded from Humanity: The Dehumanizing Effects of Social Ostracism. Journal of Experimental Social Psychology 46/1 (2010) 107-113. doi: 10.1016/j.jesp.2009.06.022

Cehajic S., Brown R. \& Gonzalez R. (2009). "What Do I Care? Perceived in Group Responsibility and Dehumanization as Predictors of Empathy Felt for the Victim Group". Group Processes and Intergroup Relations 12/6 (2009) 715-729. doi: 10.1177/1368430209347727

Çevik-Ersaydı B. S. (2011). "Dehumanization in Cartoons: A Case Study of the Image of the Turk in Asbarez Newspaper". Review of Armenian Studies 24 (2011) 103-121.

Esses V. M., Medianu S. \& Lawson A. S. (2013). "Uncertainty, Threat, and the Role of the Media in Promoting the Dehumanization of Immigrants and Refugees". Journal of Social Issues 69/3 (2013) 518536. doi: 10.1111/josi.12027

Haslam N. (2006). "Dehumanization: An Integrative Review". Personality and Social Psychology Review 10 (2006) 252-264. doi:10.1207/s15327957pspr1003_4

Haslam N. \& Loughnan S. (2014). "Dehumanization and Infrahumanization”. Annual Review of Psychology 65 (2014) 399-423. doi: 10.1146/annurev-psych-010213-115045

Heflick A. N. \& Goldenberg J. L. (2009). “Objectifying Sarah Palin: Evidence That Objectification Causes Women to be Perceived as Less Competent and Less Fully Human. Journal of Experimental Social Psychology 45/3 (2009) 598-601. doi: 10.1016/j.jesp.2009.02.008

Kırlı E. (2010). “Tanzimat Sonrası Fuhuş Hadisesine Yaklaşımda Yaşanan Değişim”. Süleyman Demirel Üniversitesi Sosyal Bilimler Enstitüsü Dergisi 12 (2010) 39-51.

Kubbealtı Lugatı. (n.d.). "Gebermek”. Kubbealtı Lugatı. Erişim Tarihi: 6 Mayıs 2019. http://lugatim.com/s/gebermek

Morris K. L., Goldenberg J. \& Boyd P. (2018). "Women as Animals, Women as Objects: Evidence for Two Forms of Objectification". Personality and Social Psychology Bulletin 44/9 (2018) 1302-1314. doi: $10.1177 / 0146167218765739$

Özgen A. (2011). "Memleket Hikâyecisi Refik Halit Karay’ın "Yatık Emine” Adlı Hikâyesi Üzerine Bir Tahlil Denemesi”. Turkish Studies 6/3 (2011) 1995-2011.

Prati F., Vasiljevic M., Crisp R. J. \& Rubini M. (2015). "Some Extended Psychological Benefits of Challenging Social Stereotypes: Decreased Dehumanization and a Reduced Reliance on Heuristic Thinking". Group Processes \& Intergroup Relations 18/6 (2015) 801-816. doi: $10.1177 / 1368430214567762$

Puvia E. \& Vaes J. (2013). "Being a Body: Women's Appearance Related Self-Views and Their Dehumanization of Sexually Objectified Female Targets". Sex Roles: A Journal of Research 68/7-8 (2013) 484-495. doi: 10.1007/s11199-012-0255-y

Refik Halit (1918a). "Yatık Emine [I]”. Yeni Мecmua 56 (1918) 78-80.

Refik Halit (1918b). "Yatık Emine [II]". Yeni Mecmua 57 (1918) 99-100.

Refik Halit (1918c). "Yatık Emine [III]". Yeni Mecmua 58 (1918) 118-120.

Rudman L. A. \& Mescher K. (2012). “Of Animals and Objects: Men’s Implicit Dehumanization of Women and Likelihood of Sexual Aggression”. Personality and Social Psychology Bulletin 38/6 (2012): 734746. doi: 10.1177/0146167212436401

TDK. (n.d.). "Hayat Kadını”. Güncel Türkçe Sözlük. Erişim Tarihi: 6 Mayıs 2019. http://tdk.gov.tr/

Toprak Z. (2015). Türkiye’de Kadın Özgürlüğü ve Feminizm: 1908-1935. İstanbul 2015.

Vaes J., Paladino P. \& Puvia E. (2011). “Are Sexualized Women Complete Human Beings? Why Men and Women Dehumanize Sexually Objectified Women”. European Journal of Social Psychology 41/6 (2011): 774-785. doi: 10.1002/ejsp.824

Yakut K. \& Yetkin A. (2011). "II. Meşrutiyet Dönemi’nde Toplumsal Ahlâk Bunalımı: Fuhuş Meselesi”. Kebikeç 31 (2011) 275-307. 
